\title{
ANALOGICAL THINKING IN THE US RESPONSE TO THE OUTBREAK OF THE KOREAN WAR, JUNE 1950
}

\author{
Erwin Tan
}

\section{Introduction}

In most of the academic literature since the introduction of the security dilemma by John Herz in 1950-51, the concept has been dominated by neorealist scholars such as Robert Jervis, Ken Waltz, Charles Glaser and John Mearsheimer. Yet, with the end of the Cold War, a growing body of literature has chosen to approach the subject from the perspective of constructivism. Thus, Alexander Wendt underlined how the notion of paradoxical security competition between defensively-minded states is itself a sociallyconstructed antagonistic relationship. Furthermore, critical constructivists, led by Karin Fierke, have underlined the role of language in giving meaning to such antagonistic relationships in international politics.

This paper seeks to build on the critical constructivist approach to analysing the security dilemma, and argues that the language of policymakers is crucial in giving meaning to interaction between states. Seen in this light, the author contends that discourse analysis of statements by the Truman Administration is instructive in delineating the processes when Washington responded to the outbreak of the Korean War in June 1950. In particular, numerous statements by Truman and his advisors, in invoking the legacy of 1930s appeasement of Nazi Germany, suggest that Washington identified North Korea as part of a monolithic communist bloc that had to be deterred, lest the events of the 1930s be replayed within the context of the Cold War.

\section{The Security Dilemma}

In introducing the concept of the security dilemma, John Herz based his definition of the phenomenon on the notion of paradoxical security competition between states that, in attempting to increase their own security through the acquisition of armaments, inadvertently arouse the fears of other states. When these other states respond by similarly arming themselves, they vindicate the fears of the first state, leading to a vicious circle of arms racing and mutual fear. Thus, for instance, Herz argued that, under the condition of anarchy, states are driven to acquire more and more power in order to escape the impact of the power of others. This, in turn, renders the others more insecure and compels them to prepare for the worst. Since none can feel entirely secure 
in such a world of competing units, power competition ensues, and the vicious circle of security and power accumulation is on. ${ }^{1}$

This definition of the security dilemma was adopted by many other scholars who followed in Herz's footsteps. Thus, for instance, Robert Jervis argued that in the absence of a supranational authority that can enforce binding agreements, many of the steps pursued by states to bolster their security have the effect ... of making other states insecure. ${ }^{\prime 2}$ At the same time, however, Jervis noted that there were conditions in international relations which pointed to the possibility of mitigating the process of security competition between states. In outlining his definition of the security dilemma, Jervis argued that the actions of states facing the security dilemma can be framed with a pair of perceptual models of interaction, which he referred to as the 'deterrence' and the 'spiral' models. ${ }^{3}$ Noting that the deterrence model operated on the assumption by policymakers that they were faced by a security threat posed by an aggressive foreign state, Jervis argued that the logical course of action within the assumptions of the deterrence model was to adopt a posture of firmness and willingness to go to war in order to communicate resolve to the opposite side. ${ }^{4}$ Furthermore, as a posture of reassurance would be interpreted as a sign of weakness, policymakers should not accept any negotiated settlement involving compromise or concessions unless the other side made greater concessions or agreed to preconditions set by the first side. ${ }^{5}$

In contrast to this, Jervis's spiral model describes a situation in which the defensive postures and arming of states result in greater insecurity for other states. He argued that 'the underlying problem lies ... in a correct appreciation of the consequences of living in a Hobbesian state of nature. ${ }^{6}$ Jervis thus wrote that a peaceful state knows that it will use its arms to protect itself, not to harm others. It further assumes that others are fully aware of this ... because the state believes that its adversary understands that the state is arming because it sees the adversary as aggressive, the states does not (sic.) think that strengthening its arms can be harmful. ${ }^{7}$

When policymakers have such benign views of their own military capabilities, they take for granted the assumption that their security postures are unambiguously defensive. As Jervis noted, however, these benign self-images may not be shared by other states. Rather, policymakers in other states may fail to see the defensive intentions of the first state and believe that these postures are driven by offensive intentions. ${ }^{8}$ Jervis argued that, in attempting to communicate resolve through the adoption of firm political and security postures, policymakers may fail to acknowledge that their actions are misperceived by their counterparts in other states as evidence of hostility. ${ }^{9}$ Under these conditions, policymakers fail to see how their military postures and capabilities,

\footnotetext{
John Herz, "Idealist Internationalism and the Security Dilemma", World Politics, Vol.2, No.2, 1950, pp 157.

2 Robert Jervis, "Was the Cold War a Security Dilemma?", Journal of Cold War Studies, Vol. 3, No.1, 2001, pp36.

3 Robert Jervis, Perception and Misperception, Princeton University Press, 1976, pp 58.

4 Ibid., pp 58-59.

5 Ibid., pp 60.

Ibid., pp 62.

Ibid., 68-69.

Herbert Butterfield, "History and Human Relations" , Indian University, Collins, 1951.

9 Robert Jervis, Perception and Misperception, pp 62-72.
} 
by inadvertently contributing to the fears of others, drive the vicious circle of increasing hostility that constitute Jervis's spiral model.

Yet, more recent scholarship has presented a particularly compelling critique of this approach to defining the security dilemma. In their 2008 book, The Security Dilemma: Fear, Cooperation and Trust in World Politics, Ken Booth and Nicholas Wheeler the aforementioned definitions of the security dilemma are based on a misunderstanding of the concept. Underlining that the word 'dilemma' implies the necessity of making a difficult choice between two alternative courses, both of which entail the possibility of a negative outcome, Booth and Wheeler argue that the security dilemma represents the necessity on the part of policymakers to choose between two equally difficult courses of action in the formulation of their security policy. Booth and Wheeler thus defined the security dilemma as a two level strategic predicament' consisting of the 'dilemma of interpretation', and the 'dilemma of response', within which the implications of Jervis's deterrence and spiral models are evident. ${ }^{10}$ Faced with the condition of existential uncertainty in an anarchic world, the dilemma of interpretation is the predicament facing decision-makers when they are confronted ... with a choice between two significant and usually (but not always) undesirable alternatives about the military policies and political postures of other entities ... [policymakers] have to decide whether perceived military developments are for defensive or self-protective purposes only ... or whether they are for offensive purposes. ${ }^{11}$

The dilemma of response follows from the dilemma of interpretation, and defines the difficult choice faced by states in formulating policy responses to a given interpretation of another state's intent. In this regard, Booth and Wheeler coined the term 'strategic challenge ${ }^{\prime 12}$ to refer to a situation where policymakers have resolved their dilemma of interpretation in the belief that another state has aggressive intentions. They described the predicament faced by statesmen; 'should they signal, by words and deeds, that they will react in kind, for deterrent purposes? Or should they seek to signal reassurance?'

Both courses of action carry an element of risk for policymakers, and this is illustrated by a simple typology of States A and B, neither of which has hostile intentions towards the other, but which have some element of suspicion in interpreting the other's intentions. Within such a context, State B may undertake a military action that, from its own point of view, is defensive and clear to others as defensive. Yet, due to the context of mistrust between both sides, State A may not share this interpretation of State B's intentions. If policymakers in State A interpret State B's intentions through the deterrence model and conclude that State B is a strategic challenge, the logical implication for State A is that it should adopt a posture of political and military firmness to communicate deterrence. Yet, in so doing, State A's subscribing to deterrence model prescriptions in resolving its dilemma of response creates a similar dilemma of interpretation for State B, which has to determine if State A's position of military and diplomatic firmness is driven by offensive or defensive intent. If State B also resolves its dilemma of interpretation in a similarly confrontational manner and responds by arming, State A believes that its security fears are vindicated and acquires more weapons. Repeated cycles of this

10 Ken Booth and Nicholas Wheeler, The Security Dilemma: Fear Cooperation and Trust in World Politics, Basingstoke: Palgrave Macmillan, 2008, pp 4-5.

11 Ibid., pp 4.

12 Ibid., pp9. 
confrontational resolution of the dilemma of response lead to what Booth and Wheeler refer to as a 'security paradox' (which forms the basis of most mainstream definitions of the security dilemma). ${ }^{13}$ Although States A and B are both arming to defend themselves, their actions, by contributing to the other's security fears, lead to an arms race and escalating hostility, resulting in reduced security for both sides. On the other hand, if State A attempts to reassure State B through not arming itself, it will face unilateral strategic vulnerability if State B turns out to be an existential strategic challenge.

\section{Analogies and the Security Dilemma}

This brief background on the definition of the security dilemma in turn leads to a further question, namely, what factors may affect a policymakers' subscription to the deterrence and / or spiral models in addressing their dilemmas of interpretation and response?

Booth and Wheeler critique the mainstream definition of the security dilemma as being overly deterministic and based on the assumption that the condition of anarchical in international relations is inescapable. ${ }^{14}$ Rather, they underline the role of human agency in how statesmen formulate security and diplomatic policy in world affairs, citing Gorbachev's adoption of New Thinking in bringing about the end of the Cold War. ${ }^{15}$ This leads to Booth and Wheeler arguing that the notion of zero-sum security competition as the basis for our understanding of the security dilemma is too deterministic in explaining international politics. In so doing, Booth and Wheeler bring our attention to the Constructivist argument that the security dilemma can be seen as a social construct resulting from antagonistic interaction between states that has turned their mutual hostility into a self-fulfilling prophecy.

The Constructivist critique of the predominantly neorealist approach to analysing the security dilemma was reflected in Alexander Wendt's Social Theory of International Politics, in which he argued that defensively intentioned states inadvertently turn into rivals not as a result of their acquisition of armaments, but rather due to their identification (be it accurate or inaccurate) of one another as acquiring such armaments for hostile purposes (ie, conquest). ${ }^{16}$ In other words, policymakers' subscription to deterrence model axioms in their resolution of their dilemmas of interpretation and response is not the result of their arms build-ups or military actions of their rivals, but rather, the images through which policymakers view their rivals. In so believing that they face an aggressor state that has to be defended against, policymakers believe that the adoption of a firm political and military response is needed to underline the credibility of deterrence. Moreover, when these same policymakers do not believe that the other side's actions are driven by fear rather than hostility - in other words, a failure to acknowledge spiral dynamics in their interaction - the notion that they are faced with a strategic challenge is further internalised, and hence, an increased inclination to subscribe to deterrence model axioms in addressing their dilemma of response in the belief that they are facing an aggressor that has to be defended against. In so doing, however, policymakers' belief that they are facing a deterrence model in their interaction with one another causes both sides to believe that their fears of one

$13 \quad$ Ibid., pp 5.

$14 \quad$ Ibid., pp 8.

15 Ibid.,pp 254.

16 Alexander Wendt, "Social Theory of International Politics", Cambridge University Press, 1999, pp 269 
another are justified as potential threats are apparently vindicated by a vicious circle of arms racing and escalating hostility.

Yet, Critical Constructivists have criticised Wendt for placing undue emphasis on the actions of states as the primary basis for analysing how relations between states are constituted. As Karin Fierke argued in Changing Games, Changing Strategies, such a perspective contradicts the constructivist principle that 'meanings in terms of which action is organised arise out of interaction'.$^{17}$ Rather, Fierke argued that, in analysing the constitution of identity, it was necessary to underline the role that language may play in giving meaning to the interaction between states, and how this contributes to the identities that states assign to one another. ${ }^{18}$ In other words, states in the security dilemma do not necessarily start out viewing each other as existential security threats. Rather, as argued by JJ Suh, an antagonistic intersubjective identity emerges as a result of repeated interactions between states based on the assumption - accurate or misleading - that they are facing a hostile entity. Seen in this light, Fierke directed our attention to the importance of viewing language as a form of action which gives meaning to agents. ${ }^{19}$ Within the context of international politics, language-acts are important in giving meaning when there are conflicting meanings to the interactions between states. ${ }^{20}$ Repeated languages acts thus contribute to the identities of states. ${ }^{21}$ Moreover, given the constructivist principle that ideas and interests are mutually constitutive, the intersubjective identities that emerge from these language-acts are reflected in how states come to see their interest vis-à-vis one another. ${ }^{22}$ In other words, a state that views another state as a potential security threat defines its own national interests in terms of arming itself to defend against the perceived threat.

The differing Constructivist approaches to analysing the security dilemma in turn underlines the importance of two factors that must be taken into account in examining how policymakers' attempts to address their dilemmas of interpretation and response may have the effect of further exacerbating tensions and causing their mutual hostility to escalate. These are, first, the historical background of the historical interaction between two states, and second, the images invoked by the language acts which parallel the emergence of a Hobbesian intersubjective identity.

In understanding how states identify each other, Fierke argued that it is important to remember the ideational context within which their interaction takes place. This accordingly requires an awareness of the culture-specific circumstances of such interaction, ${ }^{23}$ in particular past historical episodes which have been instrumental in the shaping of state's identification of their respective interests. In this regard, we may also draw on Alistair Iain Johnston's work that examines how China's past history, particularly its being bullied by the Western powers during the $19^{\text {th }}$ century, has come to

\footnotetext{
17 'Anarchy is "What States Make of It: The Social Construction of Power Politics", International Organization, Vol. 46, No. 2, pp 403.

18 Karin Fierke, "Changing Games, Changing Strategies, Palgrave Macmillan", 1998, pp 17-18.

19 Ibid., pp 17-18.

20 Ibid., pp 12, 25-26.

21 Ibid., pp 18-20.

22 Ibid., pp 32-34.

23 Ibid., pp 469.
} 
shape Chinese strategic culture in the modern age. ${ }^{24}$ Seen in this light, it may be argued that particular defining moments in history may be seen as turning points in how states conceptualise their identification of their security interests. Thus, for instance, the US entry into World War Two decisively marked America's rise as a global power as well as the end its past isolationism from world affairs.

Furthermore, the significance of defining moments in world history in how states conceptualise their interests overlaps with the other important factor that underpins the escalation of security dilemma. In their analysis of how language-acts constitute meaning in international relations, Critical Constructivists emphasise the importance of the images that are invoked by these language acts insofar as their reference to past history is concerned. In other words, critical constructivists argue that a consistent pattern of language-acts that support the implementation of government policies - for instance, official statements that justify military intervention - may be seen as a form of illocution, or an action performed by speaking. ${ }^{25}$ As noted by Kennan Ferguson, language-acts may be seen as an invocation of past history by policymakers to justify the use of military force. Although such policymakers regard war as undesirable, they nonetheless claim that it should be seen as a necessary evil resulting from extreme circumstances when a government decides to initiate military force.

The convergence of these two factors may thus be seen as analogies through which policymakers respond to the security dilemma. The invocation of defining moments in history that have marked a state's newly adopted identification of its security interests within the context of responding to the outbreak of a perceived security threat are particularly noteworthy. Language acts that place an outbreak of conflict within the context of defining moments in military history simultaneously a state's identification of its security interests and how those security interests have been shaped by such recent history.

To illustrate, let us return to the typology between State A and State B described earlier in defining the security dilemma. Within this typology is State A, which prior to its involvement Conflict $\mathrm{Z}$ had, as a result of an apparently benign political environment, believed that its security interests did not require any need for foreign policy entanglements in overseas conflicts. Nonetheless, Conflict Z escalates, resulting in an unprovoked military attack on State A which forces the leaders of State A to reinterpret their security interests, in particular, the factors that failed to prevent Conflict $Z$ from escalating into an armed attack on State A. Furthermore, given the extent to which Conflict $Z$ had led to a reinterpretation of State A's security interests, the leaders of State A continue to interpret security issues in the aftermath of Conflict $Z$ in light of the lessons which had been supposedly learnt.

Let us also suppose that, in the aftermath of Conflict B, a further conflict breaks out, which we shall refer as Conflict Y. When the leader of State A chooses to justify his military intervention response to Conflict $Y$ through language-acts that recall the legacy of Conflict $Z$, it may be argued that the response to the newer conflict is, in effect,

${ }^{24}$ Alistair Iain Johnston, "Beijing's Security Behaviour in the Asia-Pacific: Is China a Dissatisfied power?", in JJ Suh, Peter J. Katzenstein and Allen Carlson (ed.), "Rethinking Security in Asia: Identity, Power and Efficiency", Stanford: Stanford University Press, 2004, pp 35-36, 68-75.

25 Harry D. Gould, "Constructivist International Relations Theory and the Semantics of Performative Language", in François Debrix (ed.), "Language, Agency, and Politics in a Constructed World", Armonk, New York: ME Sharpe, 2003, pp 57. 
drawing on the analogy of State A's reinterpretation of its security interests which have resulted from its involvement in Conflict $\mathrm{Y}$.

\section{Truman Confronts North Korea, 1950}

The extent to which such analogies may shape policymakers' efforts to resolve their dilemmas of interpretation and response is illustrated by discourse analysis of the Truman Administration's decision to intervene in the Korean War in June 1950. This may be briefly reflected in the fundamental shift in US strategic thinking as a result of the US involvement in World War Two. Prior to 1941, the predominant sentiment of isolationism in the United States had led to Washington's policy of neutrality in response to Nazi Germany's occupation of Czechoslovakia and subsequent domination of continental Europe as well as Japan's invasion of China. To some extent, this was the result of the assumption that the United States, buffeted from the European powers and Japan by the Atlantic and Pacific Oceans, was a strategically self-sufficient island that was immune to external developments and thus had no need for foreign entanglements.

Yet, the events of 1941-1945 had a fundamental impact on US strategic thinking. In spite of having no territories close to the United States, the Japanese use of aircraft carriers made it possible to inflict extremely severe losses on the US military in the Hawaiian Islands. Armed neutrality and large oceans were no longer enough to safeguard the US from attack by foreign powers. Furthermore, the global nature of World War Two had carved out three areas of primary strategic importance in the Eurasian heartland, namely, Europe, the Middle East, and East Asia, all of which were decisive in determining the outcome of that conflict due to their high concentration of population, raw materials, and ind ustrial capacity, leading to Washington's acknowledgement of geo-strategically vital locations beyond US shores. Under such circumstances, a return to the isolationism of the pre-1941 era was no longer possible.

Further underlining the global nature of US security interests in the post-1945 world was the emergence of the Soviet Union as a rival superpower that had contiguous borders with all three vital geostrategic regions. Although the US was the sole possessor of the nuclear bomb in 1945, it had been the Soviet Union that had borne the brunt of the land war effort against Nazi Germany, and which, in terms of conventional military power, had arguably emerged from World War Two as equal to the US. This was of particular concern for the Truman Administration, given the growing suspicion between Washington and Moscow over Stalin's occupation of Eastern Europe and the imposition of Soviet-backed regimes in Poland and Czechoslovakia. These trends, coming alongside the US's existing antipathy towards Stalin's communist ideology, led to growing US fears after 1945 that the Soviet Union would be the next great security challenge to the US.

This was reflected in Truman's inaugural address in January 1949, during which he referred to communism as a 'false philosophy ... a threat to the efforts of free nations to bring about world recovery and lasting peace', against which Truman pledged to 'strengthen freedom-loving nations against the dangers of aggression. ${ }^{26}$ Furthermore, in outlining his administration's promotion of collective security under the Treaty of Rio de Janeiro, Truman underlined that 'if we can make it sufficiently clear, in advance,

26 President Harry S. Truman, 'Inaugural Address, 20 January 1949', accessed via the American Presidency Project, 5 October 2010, http:/ /www.presidency.ucsb.edu/ws/ index.php?pid=13282. 
that any armed attack affecting our national security would be met with overwhelming force, the armed attack might never occur. ${ }^{27}$

The language-acts embodied in Truman's speeches are particularly telling in defining his identification of US interests in the aftermath of World War Two. It is notable that Truman referred to the ideology of 'communism' as a threat not only to the United States, but to 'freedom-loving nations', suggesting a Manichean perspective that divided the world into 'good' ('free countries' led by the US) versus 'evil' (the Soviet-led communist bloc). Even more important was Truman's declaration that the US had to clearly communicate, 'in advance' of 'any armed attack', its willingness to use 'overwhelming force' in defense of national security, in so doing underlining the credibility of the US deterrence posture. The importance of communicating a clear threat of force is clearly an invocation of the legacy of the Sudetenland Crisis of 1938. The inability of Britain and France to communicate resolve in defense of Czechoslovakia had whetted the Nazi appetite for conquest and thus encouraged further Nazi territorial expansion the following year. Such language acts, by condemning the legacy of pre-war appeasement of aggressors whilst simultaneously referring to 'communism' as a threat to 'freedom-loving countries' in the world, suggest that Truman had come to identify the Soviet Union as harbouring a plan for world domination not unlike the visions of world conquest attributed to Hitler. In other words, the Truman Administration had, by 1950, come to the assumption that the Soviet Union was the leader of a monolithic communist bloc intent on spreading communist expansion throughout the world. In light of the analogy to Neville Chamberlain's appeasement of Hitler during the Sudetenland Crisis, the logical course of action for Washington was that the US had to be willing to undertake the use of armed force in defence of non-communist countries to avoid encouraging the Soviet Union into further adventures.

The continuity of the analogy to the run-up to World War Two was further reflected in Truman's response to the outbreak of the Korean War in June 1950. Truman later recalled his initial reaction to the news of the North Korean invasion of the South:

I remembered how each time that the democracies failed to act it had encouraged the aggressors to keep going ahead. Communism was acting in Korea just as Hitler, Mussolini and the Japanese had acted ten, fifteen, and twenty years earlier ... if this was allowed to go unchallenged, it would mean a third world war. [emphasis added] ${ }^{28}$

Equally significant, Truman equated North Korea as a Soviet satellite state on the same level as the Kremlin-controlled regimes in East Germany, Czechoslovakia and Poland; the direct implication of this assumption was that the Soviet leader Joseph Stalin had ordered the North Korean invasion of South Korea. ${ }^{29}$ This assumption was shared by Truman's advisors - the Office of Intelligence Research, for instance, claimed that the North Korean Government is completely under Kremlin control ... the move against South Korea must therefore be considered a Soviet move. ${ }^{30}$ Similarly, Chairman of the

27 Ibid., 'Inaugural Address, 20 January 1949'.

28 Truman, cited in John Toland, “ In Mortal Combat: Korea, 1950-53, New York: William Morrow and Company, 1991, pp 37.

29 Glenn D. Paige, The Korean Decision: June 24-30, 1950, New York: The Free Press, pp 1968. pp132; Jennifer Miliken, The Social Construction of the Korean War: Conflict and its Possibilities, Manchester: Manchester University Press, 2001, pp 49.

30 Miliken, The Social Construction of the Korean War, pp 49. 
Joint Chiefs of Staff Omar Bradley opined that Stalin had initiated the North Korean invasion of the South in order to test US resolve. ${ }^{31}$ Although Soviet-led military actions in Eastern Europe and the Middle East were not seen as imminent, there was general consensus in the Truman Administration that a failure to demonstrate a firm response to the North Korean invasion would undermine the credibility of the US defence posture. Given the predominant assumption that the Soviet Union was intent on seeking world domination, it was feared that the prospect of US defence posture lacking in credibility would encourage the Soviet leadership to undertake similar limited military actions to expand Soviet influence in Europe and the Middle East. ${ }^{32}$

In other words, Pyongyang's invasion of South Korea was seen as being orchestrated by a monolithic communist bloc masterminded by Stalin in Moscow. Equally significant was Truman's identification of the threat posed by the North Korean invasion for US interests in addressing his dilemma of interpretation over the outbreak of the Korean War. As Truman noted in the first of two conferences at the presidential residence at Blair House on the evening of 25 June,

I believed in the League of Nations. It failed. Lots of people thought it failed because we weren't in it to back it up. Okay, now we started the United Nations. It was our idea, and in this first big test we just couldn't let them [the South Koreans] down. If a collective system under the United Nations can work, it must be made to work, and now is the time to call their [the communists'] bluff. ${ }^{33}$ (emphasis added)

Here again, Truman's language-acts reflect the analogy of the Sudetenland Crisis and the failure of the League of Nations to confront Nazi expansionism. Although the League of Nations had been formed in the aftermath of World War One to promote a united front against wars of conquest initiated by militaristic powers, the League had failed to confront Hitler over Nazi Germany's occupation of the Sudetenland in Czechoslovakia. Instead, and based on the belief that territorial concessions would satiate Hitler, Britain and France refused to offer military support to the Czechoslovakian Government. As the historical record indicates, however, the Anglo-French failure to confront Hitler during the Sudetenland Crisis contributed to Hitler's belief that the League of Nations, without the support of a single major power, would be impotent in opposing further Nazi expansion. Shortly before ordering the invasion of Poland in September 1939 - the event that sparked the outbreak of World War Two - Hitler declared that 'our enemies are little worms. I saw them at Munich', ${ }^{34}$ thereby signifying Hitler's belief that Nazi military expansion would not be opposed. This perspective thus suggests that Hitler had instigated the Sudetenland Crisis as a means of testing the resolve of Britain and France to support the League of Nations in containing Nazi ambitions. Instead, AngloFrench appeasement of Nazi Germany in 1938, by signaling political weakness, whetted Hitler's appetite for conquest. As the outbreak of World War Two marked the failure of appeasement, the logical implication of this 'historical lesson' of 1938 was that apparently aggressive powers with ambitions of world domination would test the resolve of other powers through minor crises. In order to avert the worst possible outcome - in other

31 Paige, The Korean Decision, pp 133.

32 Ibid., pp 133.

33 Truman, cited in Miliken, 2000, pp 54.

34 David faber, "Munic, 1938: Appeasement and World War Two",Simon and Shuster, 2008, pp 391. 
words, all-out war - it would be necessary to underline the credibility of deterrence against prospective challengers to international security.

In light of this background, it may be argued that Truman's invocation of the United Nations as a successor to the League of Nations signified his belief that the League, in failing to confront Nazi Germany during the Sudetenland Crisis, was directly responsible for the outbreak of World War Two. With the Truman Administration's growing identification of the Soviet Union as a hostile power that sought to extend communist control in Europe, the implication, as far as Washington was concerned, was that the mistake of 1930s 'appeasement' of Hitler had to be avoided. Within the context of the escalating Cold War, the logical implication was that Washington had to be willing to demonstrate its willingness to intervene militarily in 'Sudetenland Crises' sparked off by the apparent Soviet ambition for power.

Equally significant was that these speech-acts took place alongside other statements by Truman and his advisors warning that the international community saw the US response to the outbreak of the Korean War as a test case for evaluating US resolve in leading international resistance to what was seen as a monolithic communist bloc intent on a project of global expansion similar to that of the Nazis. Truman declared that 'Korea is the Greece of the Far East ... if we stand up to them like we did in Greece ... they won't take any next steps. But if we just stand by, they'll move into Iran and they'll take over the whole Middle East. ${ }^{\prime 35}$ In a similar vein, the State Department's Estimates Group warned that a failure to respond to the North Korean invasion would be seen by the Kremlin as a successful indirect war aimed at increasing Soviet influence, and would be considered important [by Moscow] in connection with possible Chinese moves in support of Ho Chi Minh, Burmese Communists, or Malayan Communists; possibly, a satellite attack on Yugoslavia; and possible Soviet moves in Germany or Iran. ${ }^{36}$ [emphasis added]

Here again, we see speech-acts that cast the North Korean invasion as a precursor move that tested the resolve of the US, not only in Northeast Asia, but also in Southeast Asia, the Middle East and Europe. In other words, the tensions resulting from past episodes such as the imposition of Soviet-backed regimes in Poland and Czechoslovakia, the Berlin Blockade, the Greek Civil War, Soviet threats against Iran and Turkey, were now lumped together with North Korea's invasion of the South as well as Marxist guerrilla movements in Southeast Asia as part of a wider movement to bring about communist domination of the world. ${ }^{37}$

These assumptions were further reflected during the second Blair House conference that Truman held with his advisors on the evening of 26 June 1950. In his memoirs, Truman recalled how 'what was developing in Korea seemed to [Truman] like a repetition on a larger scale of what had happened in Berlin. ${ }^{\prime 3}$ See in this light, it may be argued that, in light of the wider background of US-Soviet Cold War antagonism and the Truman Administration's belief that the invasion of South Korea had been undertaken on behalf of a monolithic communist bloc led by Moscow, it appears that,

35 Alan Winkler, "Modern America: the United States from World War II to the Present", Harper and Row, 1985, pp 48.

36 Jennifer Miliken, "The Social Construction of the Korean War", Action Publishing Technology Limited, 2001, pp 54.

37 Ibid., pp 54-55.

38 Truman, cited in Paige, 1968, pp 170. 
by 26 June, Truman and his advisors had resolved their dilemma of interpretation in the belief that the invasion of South Korea marked a strategic challenge to US strategic and security interests. Yet, even at this stage, Washington still faced a dilemma of response. Although there was pressure to avoid a return to the appeasement of the 1930s, significant debate remained over the appropriate course of action to be adopted by the Truman Administration. In light of the rout of the South Korean army within the first day of the war, there was support for the notion of direct military intervention to aid Syngman Rhee's government.

At the same time, however, in light of the Soviet Union's newfound nuclear capability, the proximity of Mao Tse-Tung's China to the Korean peninsula as well as post-1945 war-weariness in the US, there was significant reluctance to risk World War Three, particularly given intelligence reports which claimed that Soviet forces were directly involved in the ground assault on South Korea. ${ }^{39}$ Although Truman's advisors agreed that Soviet military action in Europe and the Middle East was not imminent, there was concern that US military intervention in Korea would spark off Soviet counter-intervention, and that such a tit-for-tat sequence of actions could cause the Korean conflict to escalate into a wider war. Under these circumstances, there were concerns that direct US military intervention would run the risk of causing the conflict to escalate into World War III, involving military clashes in Europe as well as Asia. ${ }^{40}$ Furthermore, the danger of Communist Chinese military counter-intervention, either in support of North Korea or against Taiwan, was realised as a possible scenario that ran the risk of embroiling the US in all-out war with the world's most populous country. Thus, for the first two days of the Korean War, US military forces in Northeast Asia were restricted to assisting in the evacuation of US citizens from the Korean peninsula.

Yet, set against these concerns, the dominant analogy of how the 1930s appeasement of Nazi Germany had failed to prevent the eventual outbreak of World War Two proved to be the main factor that led the Truman Administration to opt for direct US military intervention in the Korean War. The influence of these factors was reflected in the political pressures in the White House as well as in Congress for an assertive response to the North Korean invasion. Even as the risk of a wider conflict with the USSR and China was recognised, such a scenario was considered the lesser of two evils compared to the prospect of failing to issue a credible assertion of US resolve. Rather, the analogy of 1938 had a threefold impact on exerting pressure on the Truman Administration to resolve its dilemma of response in favour of direct military intervention.

The first of these was reflected in the concerns within the US Department of Defense that a failure to demonstrate the credibility of the US deterrent posture would constitute a replay of the appeasement of Nazi Germany during the 1930s. Given that the failure to confront Hitler in 1938 was followed by the outbreak of World War Two the following year, the logical implication for US policy in June 1950 was that a failure to demonstrate resolve in Korea would whet further Soviet territorial ambitions, leading to an increased possibility of Stalin undertaking future foreign policy adventures elsewhere in the world. Chairman of the Joint Chiefs of Staff General of the Army Omar Bradley later reflected that here was another act of aggression that, if we appeased in this case, something else would come along, and either you appeased again or took

\footnotetext{
39 Paige, pp 172-73.

$40 \quad$ Ibid., pp 170-71.
} 
action in the next one ... one appeasement leads to another until you eventually make war inevitable..$^{41}$ [emphasis added]

Furthermore, Bradley accepted the possibility of war with the Soviet Union as an acceptable risk, as 'the choice was not ours, for the Communists had thrown down the gauntlet.' General Bradley's superior, Secretary of Defense Louis Johnston, similarly referred to the possibility of war with the Soviet Union as a 'calculated risk', whilst Ambassador-at-Large Jessup opined that 'the invasion had to be met even if it meant the beginning of World War III.' ${ }^{42}$

The analogy to the 1930s is clear. Prior to the Sudetenland Crisis of 1938, the League of Nations, Britain and France had failed to show resolve in response to Germany's re-militarisation of the Rhineland, Hitler's reintroduction of conscription, German involvement in the Spanish Civil War and the Anschluss with Austria. Furthermore, Anglo-French appeasement of Hitler over the Sudetenland Crisis convinced the Nazi leadership that further actions aimed at extending Nazi control of Central Europe would not be opposed..$^{43} 1939$ thus saw the Nazi occupation of the remainder of Czechoslovakia and the invasion of Poland the following year and the outbreak of World War Two. ${ }^{44}$ The implications of such an analogy were that limited military campaigns by an external adversary had to be interpreted as probing actions that, if not checked decisively, would lead to a wider war at a later date.

The language-acts of Bradley's testimony, placed within the context of US tensions towards the Soviet Union during the late 1940s, suggests that the US Department of Defense, saw the invasion of South Korea as part of a gradual process through which Moscow would seek to expand communist influence. Furthermore, the possibility that the Soviet Union would seek all-out conflict with the US was acknowledged as a strategic contingency that had be hedged against. Equally telling were the speech-acts of Secretary Johnston and Ambassador Jessup. The very possibility of all-out war with the Soviet Union was accepted as something that had to be risked, as the failure to do so over the invasion of Korea would, in the minds of the Truman Administration, whet the Soviet appetite for further expansion. Here again, the image of the 1930s is recalled, as the failure to confront Germany prior to 1939 caused the Nazis to undertake more and more aggressive actions, culminating in the Second World War. All-out conflict with the Soviet Union was thus a strategic scenario that the Truman Administration had to hedge against, particularly given the perception in Washington that Stalin sought to dominate the world order in much the same way that the Nazis had. ${ }^{45}$

A second effect of the analogy to 1938 on Washington's response to the outbreak of the Korean War stemmed from the US State Department's concern with affirming alliance relations in the post-1945 world order as part of the wider strategy of collective security under the Truman Doctrine of containing communism. As noted earlier, the Japanese attack on Pearl Harbor had demonstrated to the White House that armed neutrality would not protect US interests from external security threats. Rather,

$41 \quad$ Ibid.,173-74.

42 Ibid., Paige, 1968, pp 173-74.

43 David Faber, "Munich: The 1938 Appeasement Crisis", London: Simon and Schuster, 2008, pp 430-31.

44 Ibid., pp 436-37.

45 William G. Stueck, "Rethinking the Korean War: A New Diplomatic and Strategic History", Princeton University Press, 2002, pp 82. 
the global nature of World War Two and the necessity for forward airbases for the deployment of nuclear-armed B-29s underlined to Washington the importance of affirming the US security commitment to its allies in Europe and Asia. As Glenn Paige noted, 'while the loss of Korea ... would not have meant a direct threat to American military security, the President and his advisors perceived a logical progression of consequences stemming from it which would inevitably menace the safety of the United States. ${ }^{46}$ As Secretary of State, Dean Acheson had been instrumental in the formulation of the Truman Doctrine and in promoting collective security under the United Nations as a means of committing the US to the defence of Western Europe against Soviet expansion. Although the Korean peninsula had previously not been a factor in Acheson's identification of regions of vital geo-strategic interest to Washington, ${ }^{47}$ he nonetheless saw the North Korean invasion as a threat to the cohesion of the newly-formed North Atlantic Treaty Organization (NATO). Acheson believed that, if the US failed to come to the defence of a small state resisting communist expansion, the very credibility of the US security commitment to Western Europe would also come into question. As Acheson later reflected, the invasion of South Korea was a test which would decide whether our collective security system would survive or would crumble ... If we stood with our arms folded while Korea was swallowed up, it would have meant abandoning our principles, and it would have the defeat of the collective security system on which our own safety ultimately depends. ${ }^{48}$ [emphasis added]

This perspective was shared by Truman, who reflected how

Each time that the democracies failed to act it encouraged the aggressors to keep going ahead ... if the Communists were permitted to force their way into the Republic of Korea without opposition from the free world, no small nation would have the courage to resist threats and aggression by stronger Communist neighbours. ${ }^{49}$ [emphasis added]

Acheson's speech-acts once again invoke the legacy of the 1930s, drawing attention to how the US had remained aloof from the looming crises that had predated the outbreak of World War Two as well as how US neutrality during the 1930s had not stopped Japan from attacking Pearl Harbor. The obvious implication for US security was thus one that called for US intervention to assist in the defence of South Korea in order to deter the supposed monolithic communist bloc from expanding Soviet influence. In a similar vein, the speech-acts in Truman's writings underlined the US President's belief that a firm, assertive US response to the North Korean invasion was necessary to assure states in the post-1945 world of Washington's willingness to aid in their resistance against communism. From Truman's perspective, the failure of Britain and France to stand firm against Hitler in 1938 had a two-fold effect. First, it emboldened Hitler to launch further transgressions the following year; second, appeasement of Hitler in 1938 undermined any basis for a coherent alliance network against Nazi Germany. Thus, the

46 Paige, pp 176.

47 In January 1950, Acheson delivered a speech which referred to Japan and the Philippines, but not South Korea, as territories that Washington saw as crucial for a defense perimeter against the prospect of communist expansion. See 'Excerpts from Acheson's Speech to the National Press Club', 12 January 1950, http:/ / web.viu.ca/davies/H323Vietnam/Acheson. $\mathrm{htm}$, accessed 1 December 2010. went so far as to exclude South Korea from the proposed defense perimeter

48 Acheson, cited in Paige, 1968, pp 175-76.

49 David Macdonald, "Thinking History, Fighting Evil: Neoconservatives and the Perils of Analogy in American Politics", Lexington Books, pp 25. 
Czechoslovakian government, realising that resistance would be in vain, chose not to oppose the Nazi occupation. In retrospective terms, such a perspective suggests that, had Britain and France militarily intervened in support of Czechoslovakia in 1938, it would have signalled a credible threat of deterrence against aggressive states with ambitions of conquest and world domination. When this analogy is placed within the context of June 1950, the logical implication was that the Truman Administration saw South Korea as a test case through which the international community would assess the credibility of Washington's willingness to support resistance against communist expansion. ${ }^{50}$ Seen in this light, it is not surprising that the Truman Administration resolved its dilemma of response in June 1950 based on the assumption that Washington had to signal the credibility of its willingness to resist the invasion of South Korea to avoid giving Moscow the impression that the US lacked resolve, and thus avoid the supposed 1930s mistake of appeasement. ${ }^{51}$

Finally, a third area in which the analogy to 1938 shaped the Truman Administration's resolution of its dilemma of response to the outbreak of the Korean War stemmed from a realisation that a weak-willed policy would arouse domestic political controversy amongst the Republican Party. It should be noted that even before the North Korean invasion, Truman had already come under increasing criticism from conservative Republican members of Congress over what was perceived to be his lack of resolve in confronting communism. Following the collapse of Chiang Kai-Shek's government to Mao Tze Tung during the Chinese Civil War, strident demands of 'who lost China' abounded in Washington. This further underlined the urgency of an assertive US response in the eyes of Congress, as the North Korean invasion was seen as a logical follow-up by a monolithic communist bloc in seeking to further expand Soviet influence in East Asia. Thus, for instance, on 26 June, Republican Senator Styles Bridges declared that 'we can continue our present course. It is the way of appeasement. It is surrender on the instalment plan. We postpone war and we finally become the largest slave state.'52 Equally significant (and drawing on another analogy related to World War Two), Republican Senator William Knowland warned that 'time is of the essence ... we must constantly keep in mind that Holland was overrun in five days and Denmark in two [by the Nazis in 1940],' thereby underlining the urgency of a US military intervention. ${ }^{53}$ In light of the growing hysteria in the US over the prospective threat posed by communism (as reflected by communist witch-hunts instigated by Republican Senator Joseph McCarthy) as well as the narrowness with which Truman had won the 1948 presidential election, the Truman Administration saw a firm response to the North Korean invasion as necessary to deflect accusations of appeasement and avoid a political fallout in the forthcoming mid-term elections. ${ }^{54}$

$50 \quad$ Miliken, pp 55.

51 Paige, pp 178.

52 Paige, pp 151.

53 John Toland, In Mortal Combat: Korea, 1950-53, New York: William Morrow and Company, 1991, pp 41.

54 It should be noted that Truman was not the only statesman in Washington who came under pressure from Republican members of Congress who demanded a more assertive posture of anti-communism. Halberstam notes that Secretary of State Dean Acheson came under harsh criticism from Republican Congressmen such as Representative Walter Judd who felt that Acheson had not done enough to support Chiang Kai-Shek's government in the Chinese Civil War. See Halberstam, 2007, ppp174-76, 183-85, 240. 
Finally, in analysing the Truman Administration's resolution of its dilemma of response in favour of an armed response, the analogy of 1938 is again reflected in Truman's press release on 27 June, when he announced that

In Korea the Government forces, which were armed to prevent border raids and to preserve internal security, were attacked by invading forces from North Korea ... The attack upon Korea makes it plain beyond all doubt that Communism has passed beyond the use of subversion to conquer independent nations and will use armed invasion and war. It has defied the orders of the Security Council of the United Nations issued to preserve international peace and security ... I know that all members of the United Nations will consider carefully the consequences of this latest aggression in Korea in defiance of the Charter of the United Nations. A return to the rule of force in international affairs would have far reaching effects. The United States will continue to uphold the rule of law. ${ }^{55}$ [emphasis added]

The language-acts reflected in the italicized sections of Truman's speech are telling. Truman referred to 'Korea' and the 'Government forces', rather than 'South Korea', thereby implying that the government in Seoul was the legitimate government of the Korean peninsula. The activities of the forces of this 'Korea' are described as 'border and internal security', thereby further casting the government in Seoul as the rightful political authority on the Korean Peninsula. In contrast, Truman referred to 'invading forces from North Korea'; equally interesting is that Truman portrayed North Korea as acting on the bidding of 'Communism'. As noted in New York Times coverage of Truman's press release, it was clear that North Korea's invasion of the South was seen by policymakers and media in the US as an act of war on behalf of the Soviet Union. ${ }^{56}$ Moreover, it is notable that Truman's speech linked the 'invading forces' to 'the use of subversion to conquer independent nations', ${ }^{57}$ presumably a reference to the Soviet imposition of Communist regimes in Poland and Czechoslovakia, attempts to blackmail the Allies in ceding control of West Berlin, and alleged Soviet sponsorship of Greek Communists in the Greek Civil War. In other words, the language-acts in Truman's speech cast the North Korean attack as part of a concerted effort at territorial expansion by what was perceived in Washington to be a monolithic communist bloc. More significantly, as the outbreak of World War in Europe had been preceded by similar indirect actions by Nazi Germany, as reflected in the Sudetenland Crisis and Nazi involvement in the Spanish Civil War, it may be argued that the Truman Administration saw the outbreak of the Korean War as a limited war initiated by the Soviet Union to aggressively expand against US global interests. ${ }^{58}$

Equally important are the language-acts through which Truman justified US intervention in the Korean War. In his speech, Truman invoked the 'rule of law', ${ }^{59}$ thereby framing Washington's entry into the Korean war against the government in Pyongyang as a struggle of ' good (the US and the United Nations) versus bad (Communism, North Korea)'. In citing the United Nations' role in 'preserv[ing] international peace and security', the legacy of the League of Nations' failure to confront Hitler during the 1930s

55 Truman, cited in United States Government Printing Office, 1953: 36-37.

56 Anthony Leviero, "Truman Orders U.S. Air, Navy Units To Fight In Aid Of Korea; U.N. Council Supports Him; Our Fliers In Action; Fleet Guards Formosa", New York Times, 27 June 2010.

57 Truman, cited in 'The United States and the Korea Problem', pp 36-37.

58 Paige, pp115.

59 Truman, cited in 'The United States and the Korea Problem', pp 37. 
(thereby failing to maintain peace and security) comes to mind. If anything, Truman's language-acts, in invoking the specter of the 1938 Sudetenland Crisis, warned that a failure to decisively intervene in the defense of South Korea would encourage further Soviet ambitions for extending Communist influence, not only in Asia, but also Europe and the Middle East.

The numerous language-acts of 'law-and-order' in Truman's speech are equally significant. By referring to the South Korean military as being 'armed to prevent border raids and to preserve internal security', Truman cast the government in Seoul as the injured party and the victim of an unprovoked attack. Conversely, in casting the US as an upholder of international law on behalf of the United Nations, Truman clearly identified the North Korean invasion as an unprovoked 'criminal' action initiated by a 'villain' (North Korea). Under such circumstances, and in light of the US as a superpower or 'world policeman', Truman's commitment of the US military to the Korean War was effectively justified as a police action to defend South Korea against Pyongyang's 'criminal' ambition of conquest and thus contribute to regional stability against 'aggressive communist expansion' ${ }^{60}$ In invoking the 'orders of the United Nations' to justify US intervention in the Korean War, Truman's language-acts recalled US isolationism during the 1930s and that the US did not take part in the conflict until the attack on Pearl Harbor. In this regard, Truman effectively referred to isolationism as an irresponsible position that had contributed to Hitler's belief that Nazi expansion would not be opposed. As 1930s appeasement had failed to prevent the outbreak of World War Two, the logical implication of this analogy to the Sudetenland Crisis was that it was necessary to underline Washington's willingness to militarily intervene in defense of non-communist states.

Seen in this light, the impact of analogies on how Washington came to resolve its dilemmas of interpretation and response with respect to the North Korean leadership is manifest. This is further underlined by statements by Truman's successor that continued to invoke the legacy of the Sudetenland Crisis. In his State of the Union Address in 1953, President Dwight D. Eisenhower warned how the free world cannot indefinitely remain in a posture of paralyzed tension, leaving forever to the aggressor the choice of time and place and means to cause greatest hurt to us. ${ }^{61}$

In other words, the North Korean invasion of South Korea, as well as the Marxist insurgency in Indo-China were, along with the Soviet imposition of puppet governments in Eastern Europe, seen as a series of orchestrated moves aimed at achieving world supremacy. As it was assumed that the Soviet Union had now taken the mantle of an aggressive power similar to that held by Nazi Germany, most policymaking circles in Washington accepted the view that adoption of a firm posture of assertiveness was necessary to underline US resolve in resisting communism. The analogy of the Sudetenland Crisis, placed within the context of the North Korean invasion of South Korea, left its mark on the dilemma of interpretation faced by successive US administrations with the belief that the Soviet Union and its satellite states were driven by ambitions of world domination.

60 Paul G. Pierpaoli, “Truman and Korea: The Political Culture of the Early Cold War”, Columbia and London, University of Missouri Press, 1999, pp 29-30.

61 Eisenhower, State of the Union Address, 2 February 1953, http://www.presidency.ucsb. edu/ws/index.php?pid=9829 
Equally significant was that this analogy ran contrary to empirical evidence concerning the intentions of the North Korean leadership. Gavan McCormack, for instance, argued that the DPRK invasion of June 1950 was instead 'a civil war between two rival Korean regimes that stemmed from the external division of the peninsula imposed in $1945^{\prime}{ }^{62}$ Furthermore, despite casting the US involvement in the Korean War as a 'law-and-order' action to defend South Korea's 'freedom', Truman did not acknowledge the Syngman Rhee Administration's execution and torture of political prisoners even before the North invaded in June 1950, or the presence of large numbers of wartime Japanese collaborators in Rhee's government. ${ }^{63}$

\section{Conclusion}

At the same time, however, it should also be noted that analogies can also work in a converse direction, in invoking the prospect of inadvertent war resulting from miscalculation and mutual fear. In a 2003 Congressional hearing, Senator Joe Biden testified that

I do worry [Kim Jong Il] will make the mistake that is often made ... miscalculating what the response of the United States may be ... when the Russian army mobilized ... it never intended that it was going to end up in a war. ${ }^{64}$

A different analogy is invoked here. Biden's statement referred to a different crisis, the July Crisis of 1914. In her case study on that crisis, The Guns of August, Barbara Tuchman recalled how Russian and German attempts to signal deterrence through threats of mobilisation of their armies contributed to their mutual security fears, causing the crisis to escalate into the First World War. ${ }^{65}$ It may thus be argued that there are grounds for exploring how 'Guns of August' scenarios can form analogies through which policymakers can seek to identify with the security fears of one another, thereby acknowledging that their prospective adversary may be driven by fear and insecurity (hence the analogy to 1914), rather than malice and hostility (as would be suggested by the analogy to 1938).

Yet, this in turn leads to a further question - namely, even when policymakers are aware that a crisis may be the result of mutual security fears and misunderstanding rather than outright hostility (hence the 'Guns of August' analogy), they still face difficulties in adopting policies aimed at mitigating the unintended conflict underpinning such a scenario. Thus, for instance, although Biden and President Obama had, prior to their electoral victory in 2008, voiced their willingness to address North Korea's supposed security fears of the US with a promise of dialogue with Pyongyang without preconditions, it is notable that such dialogue has not occurred. It appears that the Obama Administration's lack of enthusiasm for dialogue with Pyongyang has stemmed from two factors. The first of these has been Washington's need to affirm relations

${ }^{62}$ Gavan McCormack, "Target North Korea: Pushing North Korea to the Brink of Nuclear Catastrophe", New York: Avalon, 2004, pp 8-10.

63 Jon Halliday and Bruce Cumings, "Korea; The Unknown War", London: Penguin, 1990, pp $45,72,91-92$.

64 Joe Biden, cited in 'WMD Developments on the Korean Peninsula', Hearing Before the Committee on Foreign Relations, United States Senate, 2003: 64-65.

65 Barbara Tuchman, "The Guns of August”, London: Bantam Books, 1990, pp 67-92. 
with the conservative Lee Myung Bak Administration in Seoul, which since coming into power in early 2008, has effectively repudiated the Sunshine Policy. Second, since coming into office, Obama's ambitious domestic reform agenda has led to growing criticism from Republican members of Congress; this was most clearly reflected in the Republican Party's gaining of control of the House of Representatives in during the November 2010 mid-term elections. ${ }^{66}$

Under these circumstances, it appears that the Obama Administration has chosen to avoid arousing domestic controversy or straining relations with Seoul by undertaking dialogue with the North Korean leadership as promised during his election campaign. Instead, it appears that the Obama Administration has chosen to brandish his 'hawk' credentials in his adoption of a hardline policy posture towards the DPRK. In its formulation of policy towards North Korea, the Obama Administration has evidently chosen to subscribe to the analogy of 1938. Since entering office in 2009, Obama and his advisors have demanded dismantlement of the DPRK's nuclear facilities as a precondition for dialogue, and rejected North Korean appeals for talks aimed at replacing the 1953 Armistice Agreement with a formal peace treaty unless North Korea dismantles its nuclear facilities. Furthermore, the language-acts of President Obama recall the analogy of appeasement. In his speech to the US military garrison in South Korea in November 2010, Obama recalled Truman's decision to intervene in the Korean War on the grounds that 'if we allowed the unprovoked invasion of a free nation, then all free nations would be threatened.' ${ }^{67}$

Yet, in continuing to subscribe to the analogy of the Sudetenland Crisis, the Obama Administration's refusal to engage North Korea in dialogue has arguably contributed to further insecurity on the Korean peninsula. The Bush Administration had similarly insisted on nuclear dismantlement of the DPRK as a precondition for peace talks with Pyongyang; in so doing, Bush aroused the anger of the North Korean leadership, which evidently conducted the 2006 missile and nuclear tests as a means of demonstrating DPRK resolve. This suggests a possible parallel to the 2009 North Korean missile and nuclear tests, which the DPRK evidently carried out in response to Obama Administration's hesitation to carrying out dialogue with Pyongyang and the Lee Myung Bak Administration's repudiation of the Sunshine Policy.

Seen in this light, it might be more helpful if the Obama Administration adopts a policy response that balances between the analogies of 1938 and 1914. This could involve some element of affirming Washington's willingness to defend South Korea from any further provocative behaviour by Pyongyang, alongside unofficial dialogue with North Korean leaders in order to break the current deadlock. Although this conclusion does not in anyway downplay North Korean culpability behind the November 2010 bombardment of Yeongpyong Island or the provocative nature of the DPRK's missile and nuclear tests, it suggests that a policy response that balances between the analogies to 1914 and 1938 offers the best prospect for ending the current standoff. Thus, as Senator John Kerry testified in July 2010,

Even as we are fully prepared to deter and defend against any North Korean aggression ... we must remain equally ready to pursue a peaceful, negotiated solution ... It is not enough for us to avoid another war on the Korean Peninsula. We must forge

\footnotetext{
66 'Election Results Herald New Political Era as Republicans take House', The Guardian, 3 November 2010.

67 President Obama, 'Remarks by the President Honoring Veterans Day in Seoul, South Korea'.
} 
a lasting, just peace. That is ...why it is more important than ever that we find a path forward to the resumption of dialogue with the DPRK as soon as possible. ${ }^{68}$

Seen in this regard, New Mexico Governor Bill Richardson's recent visit to Pyongyang should be seen as a form of unofficial dialogue that, if followed up with further talks between the North Korean leadership and the Obama Administration, may help to break the current impasse on the Korean peninsula. Such an approach would offer the best of both analogies, whilst simultaneously mitigating their adverse effects. A clear communication of Washington's willingness to aid in the defence of South Korea is necessary to underline to Pyongyang the prospective costs of further provocative actions by the DPRK (thus safeguarding against the analogy to 1938). At the same time, by keeping the channel for dialogue with North Korea open, it would also allow the DPRK to back down from the crisis without a humiliating loss of face.

68 Kerry, cited in Tong Kim, "Dichotomy of Obama's North Korea Policy: Deterrence and Sanctions Will Not Solve the North Korean Question without Chinese Cooperation", NAPSNet Policy Forum, August 05, 2010, http:/ / nautilus.org/napsnet/napsnet-policy-forum/ dichotomy-of-obamas-north-korea-policy-deterrence-and-sanctions-will-not-solve-the-northkorean-question-without-chinese-cooperation/. 
